\title{
PERSPECTIVES FOR THE DEVELOPMENT OF TECHNOLOGIES OF HEALTHY BAKERY AND CONFECTIONERY PRODUCTS BASED ON NON-TRADITIONAL PLANT RAW MATERIALS
}

V. Mykhaylov, O. Samokhvalova, S. Oliinyk, N. Grevtseva, A. Zagorulko, A. Zahorulko Kharkiv State University of Food Technology and Trade

\begin{tabular}{l}
\multicolumn{1}{c}{ Key words: } \\
Health bakery and \\
confectionery products \\
Plant raw materials \\
Concentration \\
Drying \\
\hline
\end{tabular}

Article history:

Received 12.11.2018

Received in revised form 30.11.2018

Accepted 14.12.2018

Corresponding author:

V. Mykhaylov

E-mail:

npnuht@ukr.net

\begin{abstract}
The article is of an exploratory nature and is devoted to the substantiation of prospects for the creation of new technologies of healthy bakery and confectionery products with the products of processing of non-traditional plant raw materials.

A team of authors from Kharkiv State University of Food Technology and Trade is carrying out systematic research on the improvement of processes and hardware design of the production of concentrated and dried products of plant raw materials processing using combined methods of heating, which promote energy- and resource saving. Within this direction, the methods for processing fruit and berry, vegetable and pine-aromatic raw materials by their concentrating by microwave treatment under vacuum, vacuum boosting with the use of new type of mixers, vibration vacuum drying and IR drying at low temperatures (within $40 \ldots 65^{\circ} \mathrm{C}$ ) are developed. Their application will allow to expand the range of additives with the original organoleptic properties and the maximum preserved content of food and biologically active substances.

Another actual trend is the creation of technologies for bakery and confectionery products with the use of secondary vegetable raw materials, in particular, crushed non-fatty germs of grain crops (sprouts of wheat germ and oats) and grape powders (from peanuts and pips separated from grape) with a high content of nutrients and biologically active substances. With their application a number of industrially tested health-improving bakery and flour confectionery products were developed. Functional-technological properties and valuable chemical composition of these additives provide opportunities for the creation of a wide spectrum of technologies for bakery and confectionery products with the increased nutritional value.
\end{abstract}

DOI: $10.24263 / 2225-2924-2018-24-6-21$ 


\title{
ПЕРСПЕКТИВИ СТВОРЕННЯ ТЕХНОЛОГІЙ ОЗДОРОВЧИХ ХЛІБОБУЛОЧНИХ I КОНДИТЕРСЬКИХ ВИРОБІВ НА ОСНОВІ НЕТРАДИЦІЙНОЇ РОСЛИННОЇ СИРОВИНИ
}

\author{
В.М. Михайлов, О.В. Самохвалова, С.Г. Олійник, Н.В. Гревцева, \\ О.Є. Загорулько, А.М. Загорулько \\ Харківський державний університет харчування та торгівлі
}

Стаття має оглядовий характер і присвячена обтрунтуванню перспектив створення нових технологій оздоровчих хлібобулочних $i$ кондитерських виробів з продуктами переробки нетрадииійної рослинної сировини.

Колективом авторів харківського державного університету харчування та торгівлі проводяться системні дослідження з удосконалення процесів $i$ апаратурного оформлення виробництва концентрованих та сушених продуктів переробки рослинної сировини із застосуванням комбінованих методів нагріву, що сприяють енерго- та ресурсозбереженню. В рамках иъього напряму розроблено способи переробки плодово-ягідної, овочевої та пряноароматичної сировини шляхом ї̈ концентрування НВЧ обробкою під вакуумом, вакуумного уварювання з використанням мішалок нового типу, вібраційного вакуумного сушіння та ІЧ-сушіння за низьких температур (в межсах $40 \ldots 65^{\circ} \mathrm{C}$ ). Їх застосування дасть змогу розширити асортимент збагачувальних добавок з оригінальними органолептичними властивостями та максимально збереженим вмістом харчових $і$ біологічно активних речовин.

Іншим актуальним напрямком є створення технологій хлібобулочної та кондитерської продукиї з використанням вторинної рослинної сировини, зокрема подрібнених знежирених зародків зернових культур (шротів зародків пшениці та вівса) $і$ виноградних порочків (зі шкірочок $i$ кісточок, відокремлених з виноградних вичавків) з високим вмістом поживних $i$ біологічно активних речовин. Завдяки їх застосуванню розроблено низку оздоровчих хлібобулочних $і$ борошняних кондитерських виробів, які пройшли промислову апробацію. Функиіонально-технологічні властивості й иінний хімічний склад цих збагачувальних добавок відкривають можливості для створення широкого спектра технологій хлібобулочних і кондитерських виробів підвищеної харчової иінності.

Ключові слова: оздоровчі хлібобулочні та кондитерські вироби, нетрадиційна рослинна сировина, концентрування, сушіння.

Постановка проблеми. Сьогодні в Україні, як і у всьому світі, спостерігається швидке розповсюдження неінфекційних хвороб аліментарного походження, пов'язаних із недостатністю в раціонах харчування життєво необхідних нутрієнтів. Катастрофічні масштаби цієї проблеми звели ії до рангу найважливіших серед питань державної національної безпеки. У відповідь на нові виклики та загрози країни Європейського регіону ВООЗ розро- 
били нову європейську політику «Здоров’я - 2020», план імплементації якої у нашій країні сформульований у проекті загальнодержавної програми «Здоров'я - 2020: український вимір», а також проекті бюро ВООЗ в Україні та Швейцарської агенції розвитку та співробітництва «Неінфекційні захворювання: профілактика та зміцнення здоров'я в Україні» [1]. Одним з основних профілактичних заходів є включення у харчові раціони продуктів 3 підвищеним вмістом харчових і біологічно активних речовин, що здатні позитивно впливати на активність та довголіття людини, підвищувати резистентність організму до захворювань. У цьому зв'язку важливості набуває проблема формування вітчизняного асортименту оздоровчих продуктів харчування, у тому числі хлібобулочних і кондитерських виробів, що традиційно користуються великою популярністю і вживаються всіма верствами населення [2; 3].

Відомо, що для корекції хімічного складу вказаної продукції, надання їй оздоровчих властивостей доцільно використовувати продукти перероби рослинної сировини - природні біокоректори 3 високою харчовою та біологічною цінністю [2-4]. Отже, актуальним є створення новітніх маловідходних і безвідходних технологій концентрованих збагачувальних сировинних компонентів на основі плодово-ягідної, овочевої та пряно-ароматичної сировини, а також технологій оздоровчих хлібобулочних та кондитерських виробів з їх використанням.

Мета дослідження: обгрунтування перспектив створення нових технологій оздоровчих хлібобулочних і кондитерських виробів з продуктами переробки нетрадиційної рослинної сировини.

Викладення основних результатів дослідження. Вітчизняний та закордонний досвід розробки технологій хлібобулочних і кондитерських виробів підвищеної харчової цінності свідчить про ефективність застосування з цією метою збагачувальних добавок з плодово-ягідної, овочевої, пряно-ароматичної та зернової сировини, у тому числі вторинної [3-15].

Важливою характеристикою збагачувальних рослинних добавок $є$ максимальне збереження біологічно активних речовин (БАР) вихідної сировини, що обумовлює пошук нових технологічних рішень під час їх отримання. Для цього використовують інноваційні способи переробки рослинної сировини, що передбачають щадні температурні режими іії обробки, в тому числі низькотемпературне сушіння, подрібнення, екстрагування, концентрування [3; 6].

Колективом авторів ХДУХТ проводяться системні дослідження щодо удосконалення процесів і апаратурного оформлення виробництва концентрованої та сушеної продукції рослинного походження шляхом застосування комбінованих методів нагріву, що сприяють енерго- та ресурсозбереженню [6; 7]. В рамках цього напряму розроблено способи переробки плодово-ягідної, овочевої та пряноароматичної сировини шляхом іiї концентрування НВЧ обробкою під вакуумом, вакуумного уварювання із застосуванням мішалок нового типу, вібраційного вакуумного сушіння та ІЧ-сушіння за низьких температур (в межах $40 \ldots 65^{\circ} \mathrm{C}$ ) [6]. Так, наприклад, використання вакуумної мікрохвильової обробки рослинної сировини дає змогу звести до мінімуму втрати харчових і біологічно активних речовин в отриманих пастах та порош- 
ках за рахунок низьких температур та рівномірного тепло- i масообміну. Розроблений НВЧ-апарат для концентрування харчових продуктів із комплексним використанням НВЧ-нагрівання та вакуумування $є$ універсальним і призначається для виробництва широкого асортименту концентрованих і сушених напівфабрикатів на основі різноманітної сировини.

Застосування концентрування в роторному плівковому апараті дасть змогу суттєво зменшити час обробки за рахунок інтенсифікації тепло- і масообміну шляхом комплексного підходу до регулювання процесів гідродинаміки плину в'язкого продукту, теплопідведення, дифузії i реологічних властивостей продуктів, при цьому плин продукту відбувається в полі дії відцентрових сил.

Використання методів роздільного концентрування 3 використанням вакуумного уварювання рідкої фази в умовах ефективного перемішування за допомогою нових конструкцій мішалок скребкового типу та віддільного концентрування твердої фази шляхом вакуумної сушки за низьких температур $45 \ldots 50^{\circ} \mathrm{C}$ створює умови для отримання пастоподібних концентратів високої якості $з$ мінімальними енерговитратами.

Застосування ІЧ-сушіння на основі гнучкого плівкового резистивного електронагрівача випромінюючого типу (ГПРЕнВТ) забезпечить рівномірність теплового потоку. Поєднання ІЧ-сушіння зі стерилізацією сприяє тривалому зберіганню продуктів переробки рослинної сировини в герметичній тарі за звичайних умов протягом $1,5 \ldots 2$ років [12].

На теперішній час удосконалено конструкції роторного плівкового апарата для концентрування плодово-ягідних паст і вальцьової ІЧ-сушарки для отримання сушеного порошкоподібного напівфабрикату. Для розроблених способів виробництва фруктових паст і порошкоподібних сушених виробів на основі удосконаленого обладнання підібрано різні композиції багатокомпонентних напівфабрикатів на основі яблук, журавлини, глоду, бузини, зизифусу, кизилу, обліпихи, хеномелесу тощо [9].

Розроблені напівфабрикати з плодово-ягідної сировини (багатокомпонентні порошки, пасти, пасто- та порошкоподібні продукти) рекомендовані як вітамінно-мінеральні добавки в лікувально-профілактичному харчуванні, наповнювачі та загусники у технологіях продукції хлібопекарської та кондитерської галузі. Вказана продукція та відповідне обладнання для іiї виробництва пройшли дослідно-промислову перевірку в умовах ФОП Романова А.Ю., ТОВ МС «Холод», ТОВ «НВК Восток-Альфа» (м. Харків).

Отримані результати вказують на перспективність удосконалення способів переробки рослинної сировини з використанням енерго- та ресурсоефективних апаратів для концентрування та сушіння. Обрані наукові підходи до здійснення процесів концентрування та сушіння плодово-ягідної, овочевої та пряно-ароматичної сировини дають змогу розширити асортимент збагачувальних добавок з оригінальними органолептичними властивостями та максимально збереженим вмістом харчових і біологічно активних речовині.

Відомо, що для збагачення хлібобулочних і кондитерських виробів ефективним є застосування вторинної зернової, плодово-ягідної та іншої рослинної сировини [3; 4; 9-14]. У цьому зв'язку актуальним є створення техноло- 
гій оздоровчої хлібобулочної та кондитерської продукції з використанням подрібнених знежирених зародків зернових культур (шротів зародків пшениці та вівса) і виноградних порошків (зі шкірочок і кісточок, відокремлених 3 виноградних вичавків).

Шроти зародків пшениці та вівса $€$ вторинними продуктами в технологіях відповідних рослинних олій, які отримують в Україні за сучасними технологіями, що забезпечують максимальне збереження природного потенціалу зернової сировини. Вони містять значну кількість біологічно цінного білка $(20 \ldots 45 \%)$, а також харчових волокон $(23 . .25 \%)$ - некрохмальних полісахаридів 3 потужними пребіотичними, детоксикаційними, імуностимулюючими властивостями. Біологічно активні речовини в досліджуваних продуктах представлені в основному вітамінами Е, $\mathrm{B}_{1}$, PР, а також такими мінеральними речовинами, як залізо, калій, магній, фосфор, натрій [3; 14].

Встановлено, що внесення шротів зародків пшениці та вівса на етапі замішування тіста в фізіологічно значимих дозуваннях (10...20\% замість пшеничного борошна) призводить до зміни його в'язкості, причому особливо істотно (в 2...4 рази) - у разі внесення шроту зародків вівса, що спричинене у 1,5..1,9 раза більшою, ніж у борошна водопоглинальною здатністю. Наявність у складі добавок амінокислот, вітамінів, мінеральних речовин сприяє активації бродильної мікрофлори i, як наслідок, більш інтенсивному перебігу мікробіологічних процесів у тісті, що приводить до прискорення кислото- і газоутворення і дає можливість скоротити тривалість бродіння тіста на 7...20\% [3].

Узагальнені результати покладені в основу технологій пшеничних хлібобулочних виробів, характерними особливостями яких $є$ підвищений вміст білка (на $10 \ldots 50 \%$ ), харчових волокон (в 1,7 ..2,0 рази), вітамінів, мінеральних речовин, а також оригінальні органолептичні показники якості та більш тривалий термін зберігання свіжості. Нові продукти рекомендовані для масового споживання, а також для оздоровчого та лікувальнопрофілактичного харчування [3; 14]. На нові види хліба зі шротом зародків пшениці затверджені в установленому порядку ТУ У 15.8-1566330-242: 2010 «Вироби хлібобулочні з продуктами переробки зародків пшениці», РЦУ 00389676.6266: 2014 на хлібець «До сніданку» 3 внесенням шроту зародків вівса і технологічні інструкції з їх виготовлення.

До перспективних добавок кондитерського виробництва також можна віднести продукти переробки виноградних вичавків. Щорічно на українських виноробних підприємствах під час переробки винограду різних сортів у великих кількостях накопичуються вичавки, що $є$ потужнім джерелом харчових волокон (целюлози, геміцелюлоз, пектинових речовин, лігніну), поліфенолів (антоціанів, лейкоантоціанів, катехінів, флавонолів тощо), макро- та мікроелементів (калію, кальцію, магнію, фосфору, заліза, цинку, кремнію, міді), вітамінів (РР, С, холіну) [3; 15].

Виноградні вичавки розділяють на складові частини - кісточки та шкірочки 3 гребенями, висушують за температури не вище ніж $60^{\circ} \mathrm{C}$, подрібнюють і отримують виноградні порошки з високим вмістом біологічно активних сполук, з яких особливої уваги заслуговують поліфеноли, що, як відомо, проявляють потужні антиоксидантні властивості. 
Вивчення технологічних властивостей порошків з виноградних кісточок та виноградних шкірочок дало змогу обгрунтувати та розробити технології борошняних кондитерських виробів - здобного печива, мафінів, пряників оздоровчого призначення 3 додаванням від 10,0 до 20,0\% дослідних добавок від маси борошна пшеничного залежно від виду порошку та виду виробу. У розроблених виробах з високим рецептурним вмістом жиру уповільнюються процеси його окиснення, що подовжує терміни зберігання продукції. Часткова заміна імпортного какао-порошку на порошки з виноградних кісточок $\mathrm{i}$ виноградних шкірочок у кондитерських виробах дає можливість знизити на $5 \ldots 7 \%$ їх собівартість. Подальші дослідження з використання виноградних порошків у кондитерській галузі спрямовані на обгрунтування технологій цукристих виробів 3 високим вмістом жиру, насамперед кондитерської глазурі [15].

Розроблені технології хлібобулочних і кондитерських виробів успішно пройшли виробничу апробацію і впроваджені на підприємствах м. Харків i Харківської області.

Проте потенціал продуктів переробки зародків пшениці та вівса, а також виноградних вичавків для створення інноваційних технологій оздоровчої продукції не можна вважати вичерпаним. Їхні функціонально-технологічні властивості й цінний хімічний склад відкривають нові можливості для створення широкого спектра технологій оздоровчих хлібобулочних i кондитерських виробів з високими споживними властивостями.

Перспективними завданнями цього напрямку досліджень $є$ :

- розробка інноваційних ресурсозберігаючих способів концентрування, сушіння рослинної сировини, за використання яких в продуктах її переробки максимально зберігається природний вміст харчових і біологічно активних речовин;

- розробка асортименту плодово-ягідних, овочевих та пряно-ароматичних паст і порошків з вирішенням завдань щодо збереження кольору вихідної сировини;

- розробка рецептур, технологій та асортименту оздоровчих хлібобулочних та борошняних кондитерських виробів з продуктами переробки рослинної сировини.

\section{Висновки}

Отже, дослідження, спрямовані на створення інноваційних ресурсозберігаючих технологій хлібобулочних та кондитерських виробів оздоровчого призначення 3 використанням нових продуктів переробки рослинної сировини 3 максимально збереженим природним вмістом харчових і біологічно активних речовин та обладнання для їх реалізації, безперечно, $є$ актуальними.

\section{Література}

1. Концепція Загальнодержавної програми «Здоров’я - 2020: український вимір». URL: https://www.kmu.gov.ua/ua/npas/244717787.

2. Joyce I. Boye. Nutraceutical and Functional Food Processing Technology. Chichester: Wiley-Blackwell, 2015. $400 \mathrm{p}$. 
3. Інноваційні технології хлібобулочних і кондитерських виробів: колект. монографія / О.В. Самохвалова та ін.; за заг. ред. канд. техн. наук, проф. О.В. Самохвалової; Харків. держ. ун-т харчування та торгівлі. Харків: Ексклюзив, 2015. 462 с.

4. Товарознавство продуктів функціонального призначення: навч. посібник / А.А. Дубініна, Т.М. Летута, М.О. Янчева та ін. Харків: ХДУХТ, 2015. 189 с.

5. Процеси виробництва багатокомпонентних паст із органічної сировини: монографія / О.І. Черевко, В.М. Михайлов, Л.В. Кіптела та ін. Харків: ХДУХТ, 2015. 167 с.

6. Погожих М.I., Пак А.О. Енергоефективні способи переробки харчової сировини: сушіння плодово-ягідної сировини: навч. посіб.; Харк. держ. ун-т харч. та торгівлі. Харків: ХДУХТ, 2015. 159 с.

7. Рязанова О.А., Кириличева О.Д. Использование местного растительного сырья в производстве обогащенных продуктов. Пищевая промышленность, 2005. № 6. С. 72-73.

8. Drying and quality characteristics of fresh and sugar-infused blueberries dried with infrared radiation heating / Junling Shi et al.; LWT - Food Science and Technology, 2008. № 41. Р. 1962-1972.

9. Дорохович А.М., Лазоренко Н.П. Маффины функционального и диетического назначения. Научни трудове на УХТ «Хранителна наука, техника и технологи 2012». Пловдив, 2012. Том 59. С. 108-112.

10. Дробот В.І. Іжевська О.П., Бондаренко Ю.В. Шрот насіння льону в технології хлібобулочних виробів. Харчова наука та технологія, 2016. Том 10. № 3. С. 76-81.

11. Wheat (Triticumaestivum L.) Bran in Bread Making: A Critical Review / S. Hemdane, Pieter J. Jacobs, E. Dornez et al.; Reviews in Food Science and Food Safety. Comprehensive, 2015. Vol. 1. P. 1-12.

12. Каліновська Т.В., Крапивницька I.О., Оболкіна В.І., Кияниця С.Г. Використання вторинних продуктів переробки винограду під час розробки інноваційних технологій кондитерських виробів. Обладнання та технології харчових виробництв: темат. зб. наук. пр. Донецького національного університету економіки і торгівлі ім. М. Туган-Барановського. 2013. № 30. С. 75-80.

13. Sensory and Consumer Perception of the Addition of Grape Seed Extracts in Cookies / G. Davidov-Pardo, M.Moreno, I.Arozarena, M.R. Marin-Arroyo, R.N. Bleibaum, C.M. Bruhn. Journal of Food Science. December, 2012. Volume 77. Issue 12. P. S430-S438.

14. Олійник С.Г. Степанькова Г.В., Самохвалова О.В., Кравченко О.І. Технологія хліба пшеничного з продуктами переробки зародків вівса та кукурудзи: монографія. Харків: ХДУХТ, 2017. $123 \mathrm{c.}$

15. Samohvalova O., Grevtseva N., Brykova T., Grigorenko A. The effect of grape seed powder on the quality of butter biscuits. Східно-Свропейський журнал передових технологій. Технології та обладнання харчових виробництв, 2016. № 3/11(81). С. 61 -66. 